\title{
PALOMAS, CÓNDORES Y GALLINAZOS (2019)
}

Borka Sattler. Editorial Horizonte.

doi: https://doi.org/10.26439/en.lineas.generales2021.n5.5429

\author{
Eliana Machado \\ Lycée Technique de Mónaco
}

Compuesta de 50 capítulos y de 251 páginas, la novela Palomas, cóndores y gallinazos versa sobre los entresijos de una pudiente familia limeña de seis hermanos -Ana, Antonia, Arturo, Carlos, Javier y Verónica-, hijos de Jorge Tejada Valdés y Aída Biondi.

La acción arranca un año después de la muerte de los padres en un accidente aéreo en Europa, cuando, para tratar del tema de la colosal herencia, Ana reúne a sus hermanos en la mansión familiar de su niñez, su locus amoenus, situada en Barranco, uno de los distritos más tradicionales de Lima, Perú. Esta vivienda juega un papel importante en la novela, ya que guarda en sus paredes la memoria de las acciones de cada uno de sus antiguos habitantes humanos, custodiados por la sempiterna presencia de sus moradores alados: las contemplativas palomas.

La estancia de los hermanos en la casona será de aproximadamente cinco semanas, tiempo que dura la acción de la novela. A lo largo de sus páginas, el lector se enterará de un sinfín de acontecimientos pasados y presentes de índole bastante variada', que tocan de lejos o de cerca al clan de los Tejada Valdés. Esos hechos contribuirán a desvelarnos el trasfondo del contexto familiar poniendo al descubierto comportamientos nada ejemplares de algunos de sus miembros, lo que desmitificará la idea primigenia de una familia perfecta, de una familia "ejemplar".

Veremos la casona familiar, el locus amoenus que le inspira a la protagonista, Ana, seguridad y confort, mostrar su doble cara, esa que se le aparece en sueños a Esperanza, la nana y guardiana mayor de los secretos, para quien aquellos muros, en los que "los espíritus se hacían presentes en sutilezas, como el crujir de las escaleras" (p. 51), son un locus terribilis:

En la madrugada una pesadilla invadió su mente, en la que vio que de los muros de la casa salían garras que aprisionaban las gargantas de sus niños y ella no podía hacer nada por defenderlos.

1. Violación dentro del ámbito familiar, adulterios, suicidio, rapto, relaciones con las mafias, fraude de identidad, atentado, asesinatos e incluso un supuesto envenenamiento, el del perro de la familia, el pastor alemán Maximiliano, son algunos ejemplos. 
-Son horribles secretos que vestidos de harapos sucios se hacen presentes para evitar la felicidad — se dijo y se despertó llorando. (p. 16)

En efecto, a lo largo de su existencia, la mansión ha sido testigo de episodios de desviación de normas sociales, como la violación de Ana años antes, o el asesinato de la pareja de Javier, Óscar Parodi, a manos de la propia Esperanza, al final de la novela:

-Ana, yo lo maté, no podía permitir que ese individuo destrozara la vida de mis niños. Era como un insecto impertinente lleno de maldad. Sé que Dios me comprenderá y tú sé feliz, mi adorada, siempre estaré contigo y con mis niños. (p. 230)

Sin embargo, en la trama de la novela todo converge, confluye hacia la difuminación de las esferas deletéreas, de las experiencias negativas vividas por cada miembro de esta familia, y se alcanza una redención a través del soterramiento en sentido propio y figurado del locus familiar y con él sus secretos inconfesables, sus "secretos algunos felices y otros angustiosos" (p. 155). Secretos que desde el principio de la novela la protagonista Ana está dispuesta a no dejar que vean la luz. Así lo afirma a su nana adorada con la que comparte algunos de ellos: "Esos secretos que están en estos muros de la casa se los llevará el viento" (p. 48).

\section{EL PESO DEL SECRETO}

No faltará a la verdad el que diga que el secreto de familia es casi un pleonasmo, ya que en la vida real toda familia tiene sus secretos, y la vida ficticia creada por la novelista Borka Sattler no es una excepción a esta regla. Así, son varios los secretos que envuelven a los miembros de los Tejada y lo que puede sorprender a ciertos lectores es que algunos de ellos no serán revelados a los familiares. Mencionaremos algunos que están relacionados con la paternidad y que contribuirán a la deconstrucción del mito de la familia perfecta de los Tejada Valdés.

Uno de ellos es el caso de la verdadera identidad del violador de Ana, entonces quinceañera, pesado secreto familiar que se llevará a la tumba la anciana Esperanza.

El propio violador, Arturo, que en el comienzo de la novela, a su llegada de Boston, pensaba sincerar su conciencia con su hermana sobre su violación, decide que será menos doloroso para ella vivir sin conocer a su agresor y padre de su hija: “Qué lograría con decirle a Ana que yo fui el causante de su infelicidad?" (p. 164). Por su parte, Ana y Esperanza nunca revelaron a Antonia, Tony, ni a los demás miembros de la familia que ella, Tony, no es su hermana, sino su hija.

En cuanto a Arturo, él es fruto de la relación de Aída con el entonces estudiante de medicina Reynaldo Vergara, poco antes de que ella se casase con Jorge Tejada, quien lo reconoció como su hijo legítimo. Dicho secreto será revelado por Esperanza a Urbano 
Rojas, reciente pareja de Ana. En lo que respecta a Carlos, él fue concebido por Reynaldo Vergara y Aída cuando ella ya se encontraba casada. Aunque el doctor Vergara sabe que Arturo y Carlos son sus hijos, este secreto no será nunca revelado a los mayores interesados.

El tratamiento que la autora aplica a los secretos familiares en su novela va de la mano con el epígrafe de Oscar Wilde que abre su libro: "Un poco de sinceridad es peligroso, pero una gran dosis es absolutamente fatal", afirmación que sugiere la idea general de la obra cuando más adelante Arturo remata: "Los secretos son necesarios en algunas ocasiones, sobre todo si no repararán nada al destaparlos. Son como las larvas en la tierra, necesarias, pero mejor dejarlas cubiertas" (p. 164).

\section{VERTICALIDAD Y REDENCIÓN}

Esta casona familiar de Barranco nos hace pensar en uno de los cuentos de la literatura universal, La bella durmiente, ya que la propiedad de los Tejada Valdés también había estado sumida en un sueño profundo a raíz de un accidente. Sobra decir que nos espera un desenlace feliz como ocurre en dicho cuento de hadas, ya que Ana encuentra el amor y la protección en la figura del capitán de la Policía de Inteligencia del Perú, Urbano Rojas, que representa el cóndor mencionado en el título y es nombrado como tal en varias ocasiones en el transcurso de la novela².

Ya hemos dicho que las paredes de la casona de los Tejada guardan la memoria y los “horribles secretos de la familia", como lo dice para sí misma Esperanza en el capítulo 1. Sin embargo, al final de la historia, la residencia es derribada y en el lugar se construirá una torre en la cual cada uno de los seis hermanos tendrá su propio departamento.

En Palomas, cóndores y gallinazos también hay espacio para el ave Fénix. En efecto, ese tramo de la novela nos remite a la mitología griega: la casona es destruida, purificada de sus males y secretos, para renacer, como el ave Fénix, de sus propias cenizas.

Asimismo, cabe notar la dialéctica horizontal-vertical en la novela que es aportada por el destino final reservado a la vivienda de los Tejada Valdés. Pasamos de un eje más bien horizontal - la casona - al vertical: de una "casa" a una "torre" en la que las propias palomas se ven contempladas con un palomar en lo más alto del edificio.

Recordemos que la verticalidad evoca la elevación hacia el cielo -ámbito de lo divino, de lo que es sagrado-y, por lo tanto, alude a la ascensión espiritual. Por consiguiente,

2. Véase los capítulos $15,28,32,36$ y 39. 
se establece una relación entre dicha verticalidad y el deseo rotundo de hundir junto con la casa los pesares del pasado familiar, así como reconstruir un nuevo capítulo de la historia de esta familia burguesa limeña. La verticalidad aparece, de este modo, como símbolo de búsqueda de redención.

\section{ALEGORÍA FAMILIAR}

Hablando específicamente del grupo "familia", los lectores se sentirían quizá tentados de ver en la historia de esta familia limeña adinerada, cuyo comportamiento va al encuentro de las reglas de las buenas costumbres occidentales, una crítica abierta a la sociedad burguesa de Lima, así como a la institución del matrimonio, sobre todo el matrimonio por conveniencia, que encierra a los personajes en una determinada situación social y los empuja a ocultar y a mentir con el fin de salvaguardar las apariencias. Sin embargo, el universo ficcional creado por la novelista Borka Sattler se nutre de hechos sociales que pueden leerse en algunos de los principales periódicos del planeta. En Palomas, cóndores y gallinazos, la autora nos muestra sin ambages la parte menos glamorosa de nuestra sociedad, la parte de la que estamos, sin duda, menos orgullosos, el conjunto funcionando, así como una alegoría de una sociedad en la que cada lector será capaz de encontrar un parecido en su propio entorno. 